\title{
The Opportunities for Bilateral Cooperation between China and Uzbekistan in the Lens of "Belt and Road" Initiative
}

\author{
Komolitdinova Kholiskhon ${ }^{1} \&$ Lv JianPing ${ }^{1}$ \\ ${ }^{1}$ College of Finance and Economics, Gansu Agricultural University, Lanzhou, Gansu, P.R. China \\ Correspondence: Lv JianPing, Gansu Agricultural University, College of Finance and Economics, Anning \\ District, 730070, Lanzhou, Gansu Province, China. Tel: 86-139-1933-9454. E-mail: 1vjp@ gsau.edu.cn
}

Received: August 10, 2020

Accepted: October 7, 2020

Online Published: October 10, 2020

doi:10.5539/ijef.v12n11p39

URL: https://doi.org/10.5539/ijef.v12n11p39

\begin{abstract}
The Belt and Road Initiative, formerly known as One Belt One Road or OBOR for short, is a global infrastructure development strategy adopted by the Chinese government in 2013 to invest in nearly 70 countries and international organizations. This initiative aims to achieve the "Chinese Dream"- globalization. The economic status of China is widely flourishing since the introduction of the One Belt One Road initiative among Central Asian-African Countries, particularly in Uzbekistan. Orientation for the five priorities of the initiative is policy coordination, infrastructure connectivity, free trade, financial integration, and soft power bonds. This research demonstrates case reports of bilateral cooperation between China and Uzbekistan, mapping political, financial, economic, and cultural interactions to each of these cooperation priorities. The researchers explored references from scientific peer review articles, e-books, annual and monthly conference reports, available books, and scientific databases and documented valuable data. The researcher evaluated each cooperative agreement and determined the mutual interest and future opportunities for bilateral cooperation between target countries. Base on the findings, it is recommended that China's political and economic interactions in Uzbekistan need further investigation in the nearest future.
\end{abstract}

Keywords: One Belt One Road initiative, globalization, bilateral cooperation, five priorities, the mutual interest

\section{Introduction}

The Ancient Silk Road was redesigned as the new global "The Silk Road Economic Belt" over the land and "21 Century Maritime Silk Road" through the marine, unimpeded trade initiative which was announced in the early fall as a "One Belt One Road" project by China in 2013. Cultural, political, economic, free trade exchange architecture are represented through developing marine routes and building the roads over the land among 68 Asian, African, European countries and about $50 \%$ of society, colossal resources in the universe and 40 percent of global GDP are encompassed in this international project (Roman \& Indra, 2019). Establishing large-scale prospects for the nations which involved joint venture, the initiative has been integrated with five aspects by the Chinese Government. These aspects-policy coordination, infrastructure connectivity, unimpeded trade, financial integration, and people to people bond-reveal the structure of cooperation. Policy coordination calls for the promotion of intergovernmental cooperation and enhancing common political trust. Infrastructure connectivity calls for connecting the regions around the OBOR route with entirely innovative infrastructure. Unimpeded trade calls removing barriers for jointly building of free trade zones. Financial integration calls for establishing a common financial system within OBOR under the AIIB, BRICS New Development Bank, Shanghai Cooperation Organization (SCO) development bank, and support the Silk Road Fund. People-to-people bond calls for the promotion of extensive cultural and academic exchange for win-win cooperation (Qian, 2017). The initiative created 6 corridors over the land from the East through CA to the West and to expand ocean-going track through the seas: The Pacific and Atlantic. Uzbekistan has a topographical central position by tying up China with Europe in the land carriageway: China-Central West Asia Economic Corridor (CCWAEC). Furthermore, China is Uzbekistan's life-tested reliable partner. The relations between China and Uzbekistan are closely connected with the history of the Great Silk Road (O'zbekiston Milliy axborot agentligi, 2017). The purpose of this article is to analyze Chinese and Uzbekistan Bilateral Cooperation in the lens of OBOR assessing five aspects of the initiative: policy coordination, infrastructure connectivity, expansion of unimpeded trade environment, financial integration, soft power initiative. It then determines mutual benefits, future opportunities of bilateral cooperation 
between Uzbekistan and China got by "OBOR". The reported information in this research is thoughtful for current and future researchers to vividly understand the positive impact of the Belt and Road Initiative with a wider knowledge of the "OBOR" in building a win-win corporation and the nature of its effect on the enlargement of the mutual collaboration between China and Uzbekistan.

\section{Methodology}

Several studies have been conducted on the bilateral cooperation of China and other Asian countries but none of them have given attention to the bilateral Cooperation between China and Uzbekistan in respect to the road and belt initiative. Therefore, this study collected, documented, and thoroughly evaluated detailed references of the bilateral agreement between the two nations. The literature search was conducted by using the following search term: "the bilateral Cooperation between China and Uzbekistan with focus on road and belt initiative". As there are few studies on this topic, the authors included available information found in scientific databases, from reading available books and reports, e-books, annual and monthly conferences reports, and from searching scholarly journals for research articles on the bilateral cooperation involved in this study. In this literature review, the authors respected the original authors' definitions, descriptions, methodology, and the reported results. During the literature review search, various information and results were obtained, but the research's objectives were prioritized. The authors are aware that there might be doubts with regard to the analytical results presented in some of the figures or tables. It should be understood, however, that each researchers uses a specific analytical tool and that it is practically impossible to streamline the results in such a way that they could be compared using the same standards. The readers are referred to the original articles for further details.

\section{Literature Review}

\subsection{Engagement of Uzbek Government to the Global Initiative}

The Belt and Road Initiative is a remarkable project that contains capital and building infrastructure system of transportations through the land, subterranean, airways and the marine (Wenxian, Ilan, \& Christoph, 2018). It is considered as an extra-large global initiative by supplying nationwide with their joint interest, tranquil trading and sharing sustainable development through the establishment of a world-wide free and advantageous design (Alzghool, 2019). One of the prior matters of the Global Initiative is relieved the obstacles of the transnational market investigating the ways to achieve excellent transport links (Liu, 2018).

The Silk Road Economic Belt adjusts the present geospatial structure of joint countries as well as the Central Asian States. Because of its geographical location, The New Silk Road is a striking possibility that provides CA with an open market, up-to-date infrastructure, and transit charges (F., 2018). As a CA Country for Uzbekistan "OBOR" is an ambitious project that can obtain the same benefit as other neighboring countries. Although "The Silk Road Economic Belt" project has been in place for almost five years, Uzbekistan has made significant strides in this short period of time. And the momentous development of friendly bilateral cooperation between the two countries will attract the attention of researchers in each of these areas. Furthermore, the Uzbek Government has encouraged China's Belt and Road Initiative since the early beginning, which is a link in the inclusive growth of target countries (Rahmatova, 2018). This timeline map describes the Chinese and Uzbek Governments initial joint steps towards the "Belt \& Road" initiative:

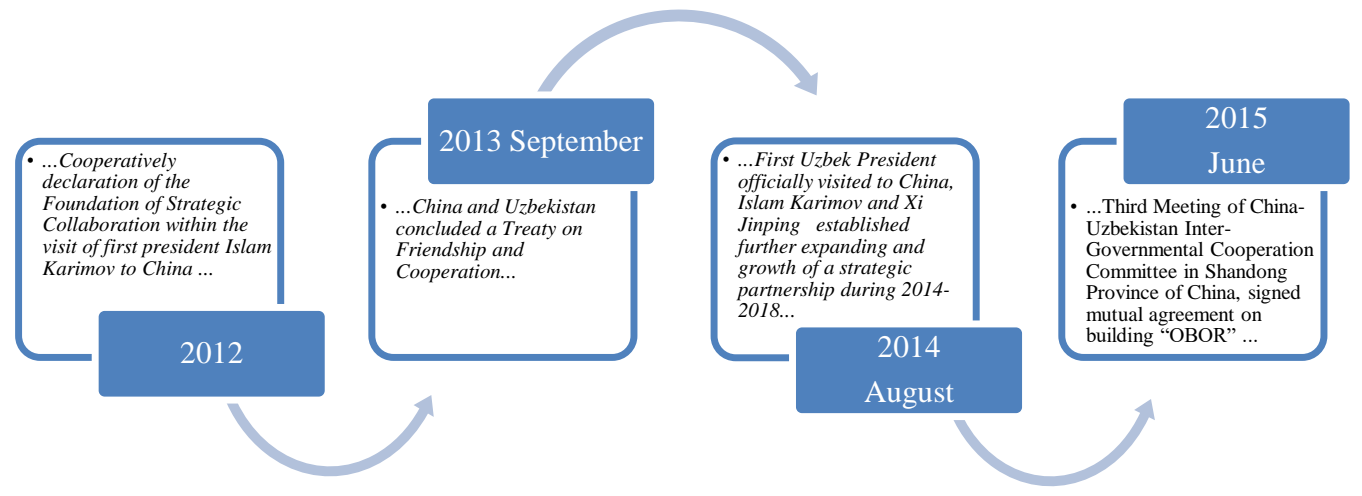

Figure 1. Timeline map of initial joint venture on "One Belt One Road"

From the perspective of China, Uzbekistan is the transit country towards the western states and one of the large natural resource exported region in Central Asia, as well as a solid and secure trade partner. Coincidentally, for 
Uzbekistan Chinese "OBOR" is the enticing concept that can be the contributor to the domestic "Action Strategy of Development" founded in 2017 by new President Shavkat Mirziyayev (Qoraboyev, 2018). Well-thought-out and planned shared interest, the position of Uzbekistan in CCWAEC and a long history of cooperation deepen the relationship between two countries, as well as tighten the presence of "OBOR" in Uzbekistan.

\section{Result and Discussion}

\subsection{Policy Coordination}

Deepening nationwide political trust and achieving possible arrangement demand in the bilateral partnership, as well as, swap the macro-policy system, thus succeeding political trust is an integral component of the B\&R initiative (Qian, 2017). It helps to deal with the massive projects and tackle problematic diversity in politics and culture surrounded by the joint countries of "OBOR" (Kwang-Jing, 2018) and build a free, wide-ranging, and stable territorial economic collaborative design that advantage all (Liu, 2018). As well as the cooperation on "OBOR" is a key factor that leads China as an exemplary partner of the Uzbek Government because of the Chinese principle refrain from interfering partner states' domestic affairs and also Chinese economic and political system can reshape the strategic orientation of the Capital city of Uzbekistan, in particular, it is a great opportunity towards victorious replacement to Soviet Union legacy (F., 2018). The diplomatic relations were established between China and Uzbekistan on the $2^{\text {nd }}$ of January in 1992, after the recognition of Uzbekistan's independence by The Peoples Republic of China at the end of December in 1991, and 14 mutual agreements were signed. Chinese President Hu Jintao backed the Andijan events of May 2005 and supported Uzbekistan's endeavor to fight against Islamic extremism, (Javaid, 2017) that paved the way combating against Islamic fundamentalism. Representatives of member countries and the president of Uzbekistan signed the joint declaration admitting The Republic of Uzbekistan as a member of SCO in Shanghai in June 2001 then the declaration on the founding of the SCO was assigned by 6 member states of SCO (Zhuangzhi, 2007). On June 24 in 2016, the summit of SCO held in Tashkent, on the occasion of the 15th anniversary of launching SCO (Note 1). Membership status in SCO has promoted multinational cooperation, expanded mutual interests, and enhanced political trust. The signing of the Strategic Corporation in mid-2012 to deepen interstate relations strengthened financial and economic stability between the states (Javaid, 2017). Political stability is the high priority of the Shanghai Cooperation Organization while "OBOR" is directed to the enlargement of economics. So, the full membership status of Uzbekistan in the SCO and the "Belt \& Road" initiative will stimulate cooperation, enlarge shared benefits and enhance political trust.

\subsection{Infrastructure Connectivity}

As the "OBOR" long term project with the potential to transform the geo-economic landscape which involves the countries from a different continent, road construction is the main hub to lead the project to be global free trading initiative. The construction of new routes, pipelines, railroads creates a great positive impact on the development of the economies of states which the road passes - through an expansion of foreign trade, investment, and infrastructure. As the ancient Silk Road, an inevitable part of today's SREB crosses Central Asian states, including Uzbekistan (Stanojevic, 2016). Moreover, the distinctiveness of Uzbekistan in Central Asia is that there is no mutual border with PRC, that makes the countries free of possible boundary strife and as the trans fixture with regional centrality advantage railroads and highways are established, simultaneously countries are attempting to develop road links (Imomov, 2018). Because of not sharing a border with China, commercial transit relations involve going through roads crossing Kazakhstan or Kyrgyzstan. From the Chinese point of view, Uzbekistan is the safe and stable, short and low costing route to the western states, the market for "Made in China" manufacture, area to import raw materials at the optimum price because of advanced transport facility and while Uzbek Government is facing various transport problems in bringing its products to the world market (Javaid, 2017), this road line is the way for double landlocked Uzbekistan towards to the open world market, road construction will contribute internal economic development of the country and at the same time government van benefit from the transit fee.

\subsection{1 “Angren-Pap" Railway}

Uzbek Angren-Pap railroad is the first tunnel built by the China Tunnel Construction Group in Central Asia in 2016 (Hu Biliang, 2019). A total of $\$ 2.090$ billion was spent on the $123.1 \mathrm{~km}$ long railway, and the $19.2 \mathrm{~km}$ long Kamchik tunnel. The Kamchik tunnel is ranked $8^{\text {th }}$ in the world in terms of complexity, $13^{\text {th }}$ in the world in terms of length and $1^{\text {st }}$ in the CIS (Commonwealth of Independent States) (Yusufbayevich, 2016a). Angren-Pap railway line is a belt connecting eastern regions with neighbor Kyrgyz Republic to the domestic railroad and plays an inevitable role as a link in the China-Central Asia-Europe economic corridor as well as "China-Kyrgyzstan-Uzbekistan" transport corridor (AGHAVNI, 2019). Initially, the Uzbek government ensured 
the development of the Angren Free Economic and Industrial Zone, and at first connect Fergana Valley with the rest of the country's railway, and later with the PRC. Thereby the link contributes to improve the quality of logistic service and reduce the cost of goods (Uzbekistan - Pap-Angren Railway Project, 2015). After the completion of "Angren- Pap" railway and various of successful joint construction, the sides ensured that there is a basis of bilateral cooperation between the Uzbek Government and PRC with the respect to Belt and Road Initiative (Buranelli, 2018) The achievements on infrastructure connectivity motivates the sides towards future cooperative projects which can contribute to the internal and external development of Uzbekistan.

\subsection{2 "Uzbekistan-Kyrgyzstan-China” Multimodal Trans-Corridor}

At the beginning of this year, the Ministry of Investment and Foreign Trade delegation had a visit to China, and they discussed on the further development of bilateral trade between Uzbekistan and China at the "Lianyungang" port and at the meeting, the parties agreed to use a "China- Kyrgyzstan-Uzbekistan" multimodal transport corridor utilizing the road transportation in the transit part "Kashgar - Irkeshtam - Osh - Andijan" (UzA, 2020a). The Cargo movement is to be carried out on the "railroad- road transportation-railroad" scheme. After the agreements and during this harsh pandemic the first batch of multimodal transit on the route "Lanzhou - Kashgar - Irkeshtam - Osh - Andijan - Tashkent - Mari” was carried out in May 2020 and showed that the prospect of a multimodal transport corridor massive enough. (Vazirligi, 2020b). The inauguration was held on June 5 in 2020 to send the first batch of 25-40 foot containers loaded electrical equipment from Lanzhou, Gansu province of China to Turkmenistan's Mari station using the multimodal transport corridor passing by Kyrgyzstan and Uzbekistan (Note 2). The Economic development requires stable transport and communication system, especially during the pandemic organizing the delivery of goods to the destination at the optimum price through shortest distance, utilizing a capable mode of transportation over the multimodal transport routes has become indispensable. And the organization of this multimodal transportation will contribute to integrate the countries' economy in which multimodal corridor passes into the international transport and trade system.

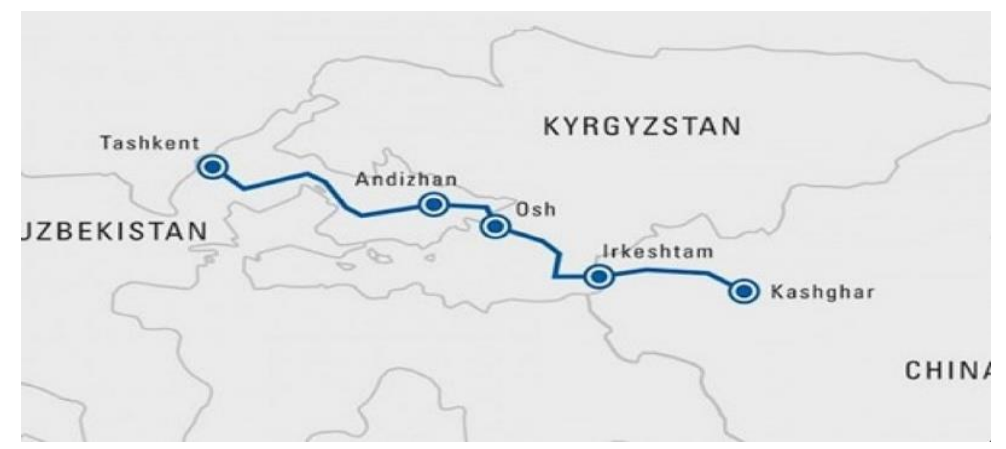

Figure 2. Multimodal Corridor map 1

Source: https://www.railfreight.com.

\subsubsection{China-Central Asia-Middle East}

The construction of a high-speed way which connects West Asia with northwest China through crossing Central Asian states has been planned by Kazakh, Kyrgyz, Uzbek, Turkmen government and Iran, China railway Authority. The scheme has been put on the "Urumqi and Yining-Almaty-Bishkek-Tashkent and Samarkand-Ashgabat" route and then final joint in West Asia via Tehran, Iran to the Persian-Gulf. But the implementation of this corridor has been delayed due to technical reasons that incompatibility of track standard in Central Asian to the standard that adopted in PRC and other vast numbers of countries (AGHAVNI, 2019).

Recently Due to the pandemic Railways have become a safe and stable means of transportation. To discuss the implementation of the Uzbekistan-Kyrgyzstan-China railway project $20^{\text {th }}$ of May online meeting initiated by the Uzbek side among Minister of Transport of Uzbekistan Elyor Ganiev, Minister of Transport and Roads of Kyrgyzstan Janat Beishenov, Director General of the Department of Foreign Capital and Foreign Investments of the State Committee for Reform and Development of the People's Republic of China. Mainly the parties deliberated the speech about the merger of the anticipated railway construction routes, technical standards used in the construction, a foundation for the plan and other organizational issues, and the proposals made in detail by China and Kyrgyzstan on the areas through which the railway can pass (Vazirligi, 2020a). If the project implemented as soon as possible, this corridor will lead landlocked Central Asia (especially double-landlocked Uzbekistan) to the World Market by the shortest and inexpensive way, at the same time China will get the benefit 
to reach the west in a short period time with low cost of transit via CA.

\subsection{Enlargement of Bilateral Trade Cooperation}

In a short time, the "Belt and Road " free trading global project has become one of the most important initiative, as well as free and prosperous trade relations among Asian, European, and African countries, along with, important in the domestic economic development of joint states. In terms of economy, China is a large new trade partner of the majority countries in the universe, the basis of machinery importer, an investor for up to date infrastructure (Dadabaev, 2018). Moreover, "OBOR" has a considerable effect on the global economy and internal growth of countries which involved joint venture especially states most in need are supported in the sector of trade, FDI, industry by (AIIB)Asian Infrastructure Investment Bank and (SWF)Sovereign Wealth Funds (Wenxian, Ilan, \& Christoph, 2018). The President of Uzbekistan Shavkat Mirziyayev said that the "One Belt One Road" project is a global forum of the $21^{\text {st }}$ Century, which aims to develop economic ties among many countries, create opportunities for trade and investment and expand other social spheres (Mihalev, 2017).

Uzbekistan has established diplomatic relations with the People's Republic of China since its independence. Recently the presence of China has become more active in Uzbek economics. According to the ITM data from 2010 to 2013, the volume of Chinese export to Uzbekistan slightly exceeded. However, in 2014-2015 the trade volume has slightly decreased, which was apparently due to the reduction of trade as a result of global energy price reduction. Especially in 2015 trade volume between China and Uzbekistan dropped significantly by 18 percent (from $\$ 4.27$ billion to $\$ 3.5$ billion). Simultaneously China and Uzbekistan's mutual agreement on the "Belt and Road Initiative" in June 2015 was a great chance for Uzbekistan to rehabilitate the growth in the trade relationships. By 2016-17 trade volume had recovered respectively and in 2018 had increased by $78 \%$, reaching a total of $\$ 6.26$ billion. Moreover, Uzbek export to China has exceeded, attaining a value of $\$ 2.32$ billion.

\begin{tabular}{|l|l|l|l|l|}
\hline Year & Trade & \multicolumn{2}{|l|}{ Uzbekistan's } & \multicolumn{2}{|l|}{ Uzbekistan's } \\
Million/USD & $\begin{array}{l}\text { Export to } \\
\text { China }\end{array}$ & $\begin{array}{l}\text { Import from } \\
\text { China }\end{array}$ \\
\hline 2010 & $\$ 2,481$ & $\$ 1,300$ & $\$ 1,181$ \\
2011 & $\$ 2,166$ & $\$ 807$ & $\$ 1,359$ \\
\hline 2012 & $\$ 2,874$ & $\$ 1,091$ & $\$ 1,783$ \\
\hline 2013 & $\$ 4,551$ & $\$ 1,938$ & $\$ 2,613$ \\
\hline 2014 & $\$ 4,275$ & $\$ 1,597$ & $\$ 2,678$ \\
\hline 2015 & $\$ 3,502$ & $\$ 1,266$ & $\$ 2,236$ \\
\hline 2016 & $\$ 3,639$ & $\$ 1,606$ & $\$ 2,033$ \\
\hline 2017 & $\$ 4,237$ & $\$ 1,474$ & $\$ 2,763$ \\
\hline 2018 & $\$ 6,266$ & $\$ 2,324$ & $\$ 3,942$ \\
\hline 2019 & $\$ 7,224$ & $\$ 2,180$ & $\$ 5,044$ \\
\hline
\end{tabular}

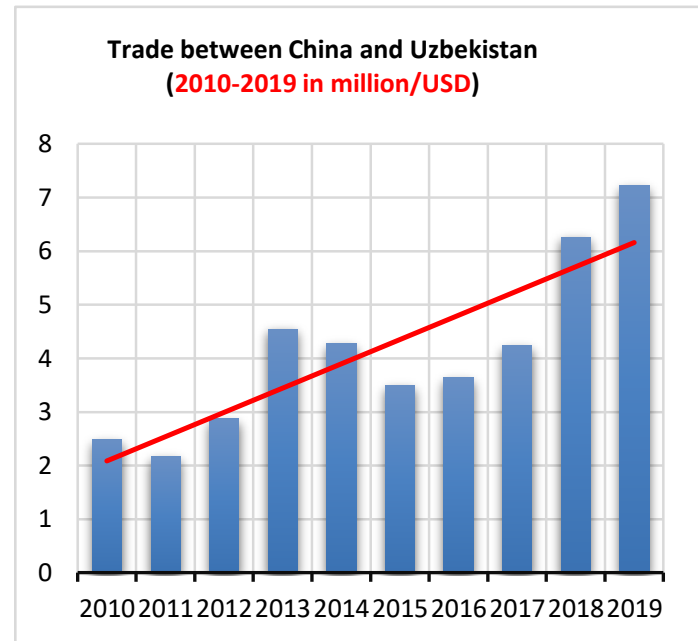

Figure 3. Trade between China and Uzbekistan (2010-2019)

Source: International Trade Center (http://www.intracen.org).

In Figure 2 the dynamics of trade between China and Uzbekistan can be observed more vividly that the trade volume has drastically increased after the joint to the "Belt \& Road" Initiative. Like other Chinese trading partners, the trade relationship with Uzbekistan is almost one-sided. China has been the first trade partner of Uzbekistan in recent years, Chinese export to Uzbekistan amounted \$5,044 billion (about 23\% of Uzbekistan's total imports and $0.2 \%$ of Chinese exports), Uzbek export to China amounted to $\$ 2,180$ billion (Approximately 0.1 percent of total Chinese import, and 14,4 percent of Uzbek export) in 2019. So, in terms of trade, China is much more important for Uzbekistan than Uzbekistan is to China. However, Uzbekistan's geographical location and political importance in OBOR are disproportionate to trade volume.

\subsection{Financial Integration}

Financial integration is an inevitable part of the project. The credit system, along with the expansion of the financial coverage of the OBOR countries through investment, as well as the prospects for currency exchange cooperation, will achieve the Chinese dream "RMB globalization" league. Besides, investing in politically stable Central Asian states will provide China with energy directly over the land and short-term access to European 
markets (Stanojevic, 2016).

Recently bilateral cooperation, between Uzbekistan and China, has deepened in energy supply and Silk Road Economic Belt further warrants this prospect (Fazilov, 2018). The predominant purpose of joining to the Belt and Road Initiative of Uzbek government was the advantage of investment, the launch of Chinese business association in Uzbekistan, and the enlargement export volume of "Made in Uzbekistan" products to countries which joint to the Belt and Road Initiative, simultaneously increasing the production capacity of local companies. At the same time, it helps for intergovernmental development. In 2018 bilateral agreements have been signed that worth 15 billion in gas and uranium mining and the bilateral cooperation has been surpassed to more than 700 (Umirdinov, 2018). A, B, and C "China-Central Asia" (from Turkmenistan via Uzbek and Kazakh regions to Chinese East-West pipeline) gas pipeline are running soundly. And through the OBOR project, China is expected to deepen its efforts to expand cooperation with Central Asian countries (Veysel, 2017), which is reflected in Chinese investment in the construction of energy pipelines. Also, the PRC has invested more than $\$ 7.8$ billion in Uzbekistan, and several large projects, including the Peng Shen industrial park, the Khojasayat section of the Dengizkul gas condensate field, the China-Kyrgyzstan-Uzbekistan transport corridor, and others have already shown a significant effect. Businesses built with Chinese capital have created more than 20000 jobs to date (Hojaev, 2018). Along with that Chinese companies have evolved into one of the largest foreign direct investors in Uzbekistan, having huge enlargement of cooperation with Uzbek enterprises. For instance, in the field of telecommunications itself ZTE, Alcatel Shanghai Bell, and Huawei Technologies have been operating for a stable existence (Weitz, 2018). And in turn, these economic and financial partnerships will flourish under the OBOR project, making wise use of bilateral opportunities.

\subsection{People to People Bond}

The five aspects of the Belt and Road Initiative: Policy coordination, Infrastructure connectivity, Free trade, and Financial integration are underpinned to People-to-people bond. And this, in turn, shows that the economic and political development of the states is inextricably linked with the development of culture, and in turn, the initiation covers all focal points of development. This coordination aims to strengthen political trust by expanding the mutual exchange of culture, encouraging win-win cooperation, stimulating harmony (Yelena, 2018). The corporation is making great strides in the field of culture, science through the use of scientific and cultural exchanges, including interstate corporations, where many students have access to foreign education under the "OBOR" project. As well as, the "Belt \& Road" initiative creates an environment that the majority of overseas students will learn the Chinese language, communicate with Chinese, and exchange international culture. And the growing digital networks in China and other "OBOR" countries, will associate nations, products, and states with means of innovation (Wenxian, Ilan, \& Christoph, 2018).

Peters and Michael illustrated the "Belt \& Road" Initiative as an umbrella that reduces the poverty by developing education and revolves the appreciation of humanity circumference international culture (Peters, 2019). And another study by Kwang-Jing Yii shows that education has a contrary relationship with economic development, however, affects the productivity of OBOR. This is since most of the participating countries are developing countries with incomplete educational systems. And to resolve this problem they recommended that the participating countries should revise and improve their academic policy through effective investment, rather than allocating funds to the education sector without proper planning. Furthermore, countries along the OBOR can share their educational resources. For instance, China encourages universities to set up campus branches in other OBOR countries for educational and cultural exchange (Kwang-Jing, 2018). Significant progress has also been made in interstate cooperation in the field of education, including Uzbekistan was one of the first Central Asian countries to promote Chinese language and culture among Uzbek students by the opening of Confucius Institutions in Tashkent and Samarkand. The opening of the Uzbek language faculty at the Shanghai International University is a sign of respect and esteem for interstate culture and with the rapid development of "Belt and Road" construction, the demand for talent working in small languages has shown a sharp trend. Besides, under the "Belt \& Road" project, Uzbek students have been awarded grants for language courses, bachelor degree, master's degree, and Ph.D. levels, and currently according to the Chinese Ministry of education about 6500 students had the opportunity to study in Chinese universities till mid-2019 (Note 3).

The important role of the OBOR project in the development of tourism in our country is that the member states of the project are among the top suppliers of most tourists in the world. To develop tourism in Uzbekistan, President Shavkat Mirziyayev offered the establishment of the "Great Silk Road International Tourism Association" in Samarkand and assemble the annual tourism forum of "OBOR" (Aripov, 2019). In the middle of November in 2019 Tashkent hosted international tourism fair "Tourism on the Silk Road" (TITF-2019) (Note 4). For the half-finished 2018, 20 thousand Chinese tourists had a visit in Uzbekistan. Between the countries, the 
quantity of tourists is about to exceed and the sides actively present prospective of tourism (Hojaev, 2018)

\section{Conclusion}

The global initiative has achieved much to date in the field of five coordination of the project among Asian, African, European Countries by maintaining political stability. Above-mentioned the cooperation between Uzbek and China has grown in the field of foreign trade, investment, transportation, logistics, education, tourism. In analyzing five priorities of the project, the conclusion to be drawn is that bilateral cooperation between Uzbekistan and China is at the stage of growth. This can be ascribed to the following elements: bilateral cooperation between two countries with the long-standing experience and mutual benefit make the aspects of the "Belt \& Road" initiative free of political objectivity; The potential economic benefit of this partnership is noteworthy in "OBOR", and it is the Chinese interest to connect the land carriageway to the west market via CA including Uzbekistan as a transit state, uplift the Chinese RMB global level regionally by bringing investment and 'made in China' products to the most populated Uzbekistan in CA state; import the Uzbek energy with optimum price by the short distance over the land. At the same time, from Uzbek perspective, bilateral cooperation with China under "OBOR" Chinese Investment on Energy investigation, telecommunication, construction of infrastructure contributes Economic development of Uzbekistan and create job opportunity for Uzbek nations; Initiative connect landlocked Uzbekistan not only to China but also lead to the world market providing safe and secure; in the field of education Uzbek students have chance to get Chinese education and nations along the "OBOR" grand to develop tourism in Uzbekistan with great historical monuments. Cooperation with China and other countries under OBOR motivates the Uzbek people not only internally but also externally, the economic, and political stability of Uzbekistan, and the ability of this global project to bring the Uzbek state to the global scale. Integration into the international logistics system, joint investments, and infrastructure play an important role in bringing Uzbek products to the world market. With political stability under "OBOR", Uzbekistan and Chinese partnership will flourish and the project will give future potentials for both countries. Such as the construction of a new transport link take Uzbekistan to the Persian Gulf and Uzbekistan has the opportunity to improve domestic production and export to states along the "OBOR", simultaneously China's hand will reach to Europe over the land.

\section{Acknowledgments}

The authors are very grateful to Prof. Dou Xuecheng his motivation, enthusiasm, and immense knowledge and Mr. Mukut Sikder for the technical guidance during the data collection. Special thanks and appreciations to Mr. James Blackar Mawolo and Mr. Yang Ping for their comments and analysis which improved the Manuscript significantly. This research could be impossible without the assistance rendered from the aforementioned personalities.

\section{References}

Aghavni, H. (2019). China's “One Belt, One Road” Initiative and Its Impact in Central Asia. In S. Ruben (Ed.), The Countries and Peoples of the Near and Middle East (Vol. XXXII, pp. 284-319). Retrieved March 28, 2020, from http://www.orientcpnme.am/

Alzghool, M. (2019). China's "Belt and Road" Initiative and its impact on the global economy. Retrieved May 05, 2020, from https://www.researchgate.net/publication/334761289

Aripov, E. (2019, November 18). Development Strategy Center. Retrieved from https://strategy.uz/index.php?news=693\&lang=en

Biliang, H. (2019). Building the Belt and Road: The Impact on China and Central Asia. In M. Emerson, H. Biliang, R. M. Nag, \& S. Ferede (Eds.), 2019 Eurasia Meeting. Belt and Road Initiative in Central Asia and the South Caucasus: The Perspectives of China, Russia, the Europian Union, India and United States of America (pp. 2-6). Gerzensee, Switzerland.

Buranelli, F. C. (2018, January). One Belt, One Road and Central Asia: Challenges and Opportunities. In S. L. Cheng (Ed.), The Beelt and Road Initiative in the Global Arena: Chinese and Europwan Perspective (pp. 207-230). https://doi.org/10.1007/978-981-10-5921-6_12

Dadabaev, T. (2018, July/August). The Chinese Economic Pivot in Central Asia and Its Implications for the $\begin{array}{lllll}\text { Post-Karimov Re-emergence of Uzbekistan. Asian Survey, 58, } & \text { 754-769. }\end{array}$ https://doi.org/10.1525/as.2018.58.4.747

F., I. (2018). The Impact of the Belt and Road Initiative on Central Asia: Building New Relations in a Reshaped Geopolitical Scenario. In A. I. Zhang W. (Ed.), China's Belt and Road Initiative. Palgrave Studies of 
Internationalization in Emerging Markets (pp. 135-142). Palgrave Macmillan, Cham. https://doi.org/10.1007/978-3-319-75435-2_8

Fazilov, X. C. (2018, December). Re-centering Central Asia: China's "New Great Game" in the old Eurasian Heartland. Palgrave Communications, 4(1), 1-12. https://doi.org/10.1057/s41599-018-0125-5

Hojaev, A. (2018, October 31). Svobodnoe mnenie. Retrieved January 2020, from https://nuz.uz/svobodnoe-mnenie/36535-uzbekistan-i-novyy-shelkovyy-put.html\#

huaxia (Ed.). (2019, October 31). Retrieved July 2020, from Xinhua: http://www.xinhuanet.com/english/2019-10/31/c_138518582.htm

Imomov, I. (2018, June 20). Impact of «One Belt, One Road» initiatives to the economy of Central Asian countries. International Journal of Business and Economic Development, 31-34.

Javaid, D. F. (2017, July). Sino-Central Asian Relations and Sino-Us Rivalry in the Region: A Study. Grassroot Research Journal, 51, 315-330. Retrieved https://www.researchgate.net/publication/317503674_SINO-CENTRAL_ASIAN_RELATIONS_AND_SIN O-US_RIVALRY_IN_THE_REGION_A_STUDY

Kwang-Jing, Y. K., Kai-Ying, B., Wei-Yong, C., Yee-Lee, C., \& Ching-Mei, L. (2018, November 8). Is Transportation Infrastructure Important to the One BeltOneRoad(OBOR)Initiative?EmpiricalEvidence from the Selected Asian Countries. Sustainability, 10. https://doi.org/10.3390/su10114131

Liu, W. D. (2018, July 27). A discursive construction of the Belt and Road Initiative: From neo-liberal to inclusive globalization. Journal of Geographical Sciences, 1199-1214. https://doi.org/10.1007/s11442-018-1520-y

Liu, X. (2018, February). Analysis of logistics service supply chain for the One Belt and One Road initiative of China. Transportation Research Part E, 117, 23-39. https://doi.org/10.1016/j.tre.2018.01.019

Mihalev, I. (2017, May 15). Jamiyat. Retrieved March 2020, from https://sputniknews-uz.com/society/20170515/5405263/Ipak-yoli-chorrahasida-joylashgan.html

OECD. (2018). OECD Business and Finance Outlook 2018. Paris. doi:10.1787/9789264298828-en

O'zbekiston, M. (2017, May 12). O'zbekiston - Xitoy: Strategik sheriklik va do'stlik munosabatlarini yanada rivojlantirish yo'lida. Retrieved from http://uza.uz/uz/politics/o-zbekiston-xitoy-strategik-sheriklik-va-do-stlik-munosabatl-12-05-2017

Peters, M. A. (2019, May 19). China's belt and road initiative: Reshaping global higher education. Educational Philosophy and Theory. https://doi.org/10.1080/00131857.2019.1615174

Qian, Y. (2017, July). The Belt and Road initiative: reshaping the global value chain. The Association of Chartered Certified Accountants.

Qoraboyev, I. (2018). The Belt and Road Initiative and Uzbekistan's New Strategy of Development: Sustainability of mutual relevance and positive dynamics. Uzbek Journal of Legal Studies, 2-3.

Rahmatova, D. (2018, May 14). Sputnik. Retrieved from https://oz.sputniknews-uz.com/politics/20180514/8204883/Ozbekistondagi-Xitoy-elchisi-Bir-kamar-bir-yol -loyihasi-istiqbollari-haqida-gapirdi.html

Roman, V., \& Indra, O. (2019). China's Belt and Road Initiative through the Lens of Central Asia. The prospects for Economic and Financial Cooperation. (pp. 115-133). Retrieved 05 27, 2020, from file:///D:/research\%20materials/articles/BRI\%20central\%20asia_book_chapter.pdf

Stanojevic, N. (2016, January-March). The New Silk Road and Russian Interests in Central Asia. The Review of International Affairs, LXVII, 142-161. Retrieved June 07, 2020, from https://www.diplomacy.bg.ac.rs/pdf/ria/2016/RIA-1161_2016.pdf

Umirdinov, A. (2018, July 11). One Belt One Road Initiative: How to Regulate Chinese Dragon in Central Asia. Society of International Economic Law (SIEL), Sixth Biennial Global Conference. https://doi.org/10.2139/ssrn.3210385

UzA. (2020a, June 10). World. (UzA, Ed.) Retrieved July 2, 2020, from http://www.uza.uz/oz/world/khitoy-ir-iziston-zbekiston-multimodal-transport-y-lagida-bi-10-06-2020

Uzbekistan - Pap-Angren Railway Project, 88015 (February 02, 2015). Retrieved from http://documents.worldbank.org/curated/en/579571468301525990/Uzbekistan-Pap-Angren-Railway-Project 
Vazirligi, O. R. (2020a, May 20). mintrans.uz/ News. Retrieved from https://mintrans.uz/news/o-zbekiston-qirg-iziston-xitoy-temir-yo-li-qurilishi-masalasi-muhokama-qilindi

Vazirligi, O. R. (2020b, June 5). mintrans.uz/News. Retrieved from https://mintrans.uz/

Veysel, T. (2017, October 30). China's Belt and Road Initiative: at the crossroads of challenges and ambitions. The Pacific Review, 31, 373-390. https://doi.org/10.1080/09512748.2017.1391864

Weitz, R. (2018, January). Uzbekistan's New Foreign Policy: Change and Continuity under New Leadership. Central Asia-Caucasus Institute \& Silk Road Studies Program. Retrieved July 2020, from file:///D:/research\%20materials/07.08/foreign\%20policy\%20of\%20UZB.pdf

Wenxian, Z., Ilan, A., \& Christoph, L. (2018). China's Belt and Road Initiative Changing the Rules of Globalization.

Yelena, S. L. U. (2018). "Human Silk Road": The People-to-People Aspect of the Belt and Road Initiative. In M. Laruelle (Ed.), China's Belt and Road Initiative and Its Impact in Central Asia (pp. 109-125). Washington.

Yusufbayevich, A. A. (Ed.). (2016a, June 23). Media. Retrieved July 2020, from https://www.gazeta.uz/ru/

Zhuangzhi, S. (2007, January). The Relationship between China and Central Asia. Retrieved from file:///C:/Users/Professional/Desktop/research\%20materials/articles/central\%20asia\%20and\%20china.pdf

\section{Notes}

Note 1. Ministry of Foreign Affairs of the Republic of Uzbekistan, Press service, Documents https://mfa.uz/en/press/sco-uzbekistan/documents/

Note 2. Axborot-tahliliy media markazi, Birinchi konteyner poyezdi "Xitoy-Qirg'iziston-O'zbekiston" multimodal yo'nalishi bo'ylab yo'lga chiqdi, https://railway.uz/uz/informatsionnaya_sluzhba/novosti/19057/

Note 3. Kun.uz, China's Ministry of Education reveals number of Uzbek students studying at universities in PRC, https://kun.uz/en/news/2019/10/21/chinas-ministry-of-education-reveals-number-of-uzbek-students-studying-atuniversities-in-prc

Note 4. Silk Road International University of tourism, news, 25TH TASHKENT INTERNATIONAL TOURISM FAIR “TOURISM ON THE SILK ROAD» - TITF-2019, http://old.univ-silkroad.uz/en/yangilklar/295.aspx

\section{Copyrights}

Copyright for this article is retained by the author(s), with first publication rights granted to the journal.

This is an open-access article distributed under the terms and conditions of the Creative Commons Attribution license (http://creativecommons.org/licenses/by/4.0/). 